\title{
Küreselleşme Sürecinin Havayolları İşletmeleri Üzerine Etkisi ve Sonuçları
}

\author{
Murat ESIN ${ }^{1}$ \\ Murat DÜZGÜN²
}

\begin{abstract}
ÖZ
Çok boyutlu bir kavram olan küreselleşme en uzaktaki ülkelerin ve/veya yerleşimlerin birbirleriyle ilişkilendirildiği ve dünya genelindeki ekonomik, siyasal, teknolojik ve kültü̈rel ilişkilerin yoğunlaşmasını ifade etmektedir. Günümüzde uzaklık tanımaksızın ülkeler arasında sadece ekonomik konuda iş birlikleri oluşmamış bunun yanı sıra, teknik, finansal, ticari, işletmecilik ve kurumsal konularda iş birlikleri gerçekleştirilmiştir. Böylece, insanlartn veya üretilen bir ürünün güvenli ve konforlu bir şekilde ve en ksa süre içerisinde bir yerden başka bir yere taşınması sağlanmıştır. Bunun gerçekleștirilmesinde havayolu taşımactlı̆̆ da özel bir öneme sahip olmuştur. Bu süreçte, havayolu işletmeleri küreselleşme sonucu yaşanan yüksek rekabete ve yeni oluşan ekonomik düzene uyum sağlayacak değişimler içerisine girmişlerdir.
\end{abstract}

Bu çalışmada küreselleşmenin etkisiyle yaşanan değiş̧imler incelenmeye çalışılmıştır.

Anahtar Kelimeler: Küreselleşme, Havayolları, Stratejik İttifaklar, Havayolu Taşımacılı̆̆ı

The Effect and the Result of Globalization process on the Airline Companies

\begin{abstract}
Globalization, a multimensional concept, refers to the concentration of economic, political, tecnological and cultural relations around the world, where the farhest countries and/or settlements are associated with each other.Today, technical, financial, commercial, operational and institutional cooperation have also been established besides economic cooperation between countries regardless of distance. Thus, it is ensured that people or a product can easily be moved from one place to another safely and comfortably and within the shortest time. Air transportation has a particular importance in achieving this. During this development, airline companies have made improvements to cater for high level of competition and new economic system resulting from globalization.

This study is focused on review and analysis of changes due to effect of globalization.
\end{abstract}

Keywords: Globalization, Airlines, Strategic Alliances, Air Transportation

\footnotetext{
${ }^{1}$ İstanbul Medipol Üniversitesi, Siyaset Bilimi ve Uluslararası İlişkiler Doktora Öğrencisi, muratesin59@gmail.com ORCID ID: 0000-0002-7408-2745

2 Dr.Öğr.Üyesi, İstanbul Medipol Üniversitesi, İşletme ve Yönetim Bilimleri Fak. Havacıllk Yönetimi Bölümü mduzgun@medipol.edu.tr ORCID ID:0000-0002-8683-8925
}

Makale Geliş Tarihi: 16.12.2020, Makale Kabul Tarihi: 18.04.2021

ARAŞTIRMA MAKALESİ (Research Article)

* Bu makale intihal programında taranmış ve en az iki hakem incelemesinden geçmiştir. (This article has been scanned via a plagiarism software and reviewed by at least two referees).

Doi: https://doi.org/10.51524/uhusbad.841766 


\section{Giriş}

Tüm dünyada ve tüm sektörlerde değişimi ve gelişimi etkileyen en önemli faktör de küreselleşme olmuştur. Değiş̧en dünya düzeninde bu etkenler ile insanların yaşamları, sosyal ve ekonomik olguları değişmekte ve bu değişime de hem insanlar hem de sektörler tepkiler vermektedir.

Günümüzde en hızlı gelişim gösteren sektörlerden birisi olan hava taşımacılığı sektörü de küreselleşme sürecinden payını almış, zaman içinde büyük değişimler göstermiş̧ir. Havayolu taşımacılığı bir ülkenin sosyo-ekonomik yapısı ve gelișmișlik düzeyi ile orantılı bir olgu olduğu için, büyüyen ve gelișen bir havayolu sistemi bir ülke için artan refah seviyesi ve artan kültürel yapı anlamına gelmektedir.

Havayolu sektöründe faaliyet gösteren işletmeler de sektörün geçirdiği değişimi yaşamışlar küreselleşme sonrası bir takım yeni düzenlemelere gitmişlerdir. İşletmeler, artan rekabet unsurları, artan dışa açılma ve küresel bir havayolu olma baskıları ile karşı karşıya gelmekte ve bu etkenlere karşı yeni çözümler geliştirip, yeni yönetim teknikleri ile bu çözümleri hayata geçirmeye çalışmaktadırlar.

Küreselleşme sürecinin havayolu taşımacıllı̆ında ve havayolu işletmelerinde yarattığı en önemli değişimler ise, işletmelerin maliyet politikalarının değişimi, işletmelerin toplam kalite yönetimi felsefesini benimsemeleri, işletmelerin iş birliklerine gitmeleri ve işletmelerin düşük maliyetli havayolu kimliğine bürünmek istemeleri olarak karşımıza çıkmıştır. Küreselleşme ile havayolu işletmelerinde nelerin değiştiği ve işletmelerin bu değişime nasıl cevap verdiği büyük önem arz etmektedir.

\section{Küreselleşmenin Kavram ve Tanımları}

\subsection{Kavramlar ve Tanımlar}

Küreselleşme birçok anlamı içerebilmektedir. Ancak genel kabul görmüş olan tanımlamada küreselleşmeden, ekonomik faaliyetlerin;(sermaye, yatırım ve ticaret hareketlerinin) yanında işgücünün ve iş insanlarının dolaşımı, teknoloji transferi yolu ile de tüm ilişkilerin uluslararası düzeye taşınması anlamı çıkarılmaktadır (Ülgen ve Mirze, 2014:309).

Farklı araştırmacılar tarafından küreselleşme farklı şekillerde anlaşılmakta olup, genellikle dünya çapındaki iletişimlerin artan hız, yoğunluk ve kapsamını ifade eder. Bu süreç, devletlerin gücüne zayıflatma, artırma veya dönüștürme șeklinde etkileri olabilir. Küreselleşme karşıtları, şirketlerin artan gücüne karşı çıkmakla beraber, kendi aralarında taktikler ve hedef konusunda uzlaşamamaktadırlar (Goldstein ve Pevehouse, 2015: 79).

Aslında Dünya tarihi farklı küreselleşme evreleri geçirmiştir. Dünya ticaretinin gelişmesinde tarihi öneme sahip olan ipek ve baharat yolları farklı toplum ve kültürler arasında ikili ilişkilerin artmasına neden olmuştur. Ayrıca, Roma ve Osmanlı İmparatorluğu gibi İmparatorluklar yönetim İlkeleri, diğer ülkelerin ekonomik, siyasal seçeneklerini belirleyebilmeleri bakımından küresel bir nitelik taşıyorlardı.

Böyle bir küresel nitelik I. Dünya Savaşı öncesinde, coğrafi keşifler ve sömürgecilik faaliyetleriyle dünyada hâkimiyet kuran Büyük Britanya İmparatorluğunu tanımlayan en büyük temel özellikti. I. Dünya Savaşı sonrası ortaya çıkan dünya düzeninde A.B.D. diğer ülkelerin siyasi ve ekonomik seçeneklerini belirleyen küresel bir lider konumuna gelmişti.

Dünya siyasetinin işleyişinde küreselleşme paradigması 1980'lerden beri popüler olmuş, karşıllklı bağımlılı̆̆ın gelişmesi ve küresel bağlantılar ile dünya siyasetinin dönüştüğü inancı hakim olmuştur. Buna göre, dünya artık birbirinden bağlantıları kopuk değil, daha uyumlu bütünleşmiş tek dünya olarak işlemektedir (Heywood, 2016: 27).

Ancak, bugün küreselleşme denildiği zaman, 1980'lerden günümüze devletler, kültürler, ekonomiler ve hatta bireyler arasında yaşanan yaygınlaşma, derinleşme ve hızlanma olguları anlaşılmalıdır.

Yaygınlaşma, dünyanın herhangi bir yerinde meydana gelen bir gelişmenin veya yeniliğin dünyanın diğer bölgelerinde de önemli ciddi tesir ve sonuçlar yaratmasıdır. 
Buna göre dünyanın bir bölgesinde meydana gelen ekonomik kriz, siyasal huzursuzluk ya da terör eylemi dünyanın farklı bir bölgesinde işsizlik, istikrarsızlık, göç veya güvensizlik olarak ortaya çıkabilir. (Örnek:2008'de A.B.D.deki ekonomik krizin kısa sürede tüm dünyaya yayılması).

Yaygınlaşma sürecinin yarattı̆̆ önemli etkilerin çok güçlü bir şekilde hissedilmesi de derinleşme olgusunu meydana getirir. Bu durma örnek olarak Sars virüsü, kuş gribi veya terör eylemleri bu duruma örnek olarak verilebilir.

Hızlanma, yaygınlaşma ve derinleşme süreçlerinde yaratılan etkilerin artık çok hızlı bir biçimde yaşanmasıdır. Örnekler: Facebook ve twitter mesajları, msn messenger, skype, whatsapp gibi çeşitli sohbet yazılımları sayesinde yüksek ritimli bir dünyada yaşıyoruz (Keyman vd.,2015:26).

Küreselleşmenin yarattığg yukarıda açıklanan üç olgunun yalnızca iletişim ve bilişim alanlarıyla sınırlı olmadığını ve küreselleşmenin ticaret ve finans İlişkileri temelinde ekonomik alanda da çok güçlü olduğunu biliyoruz. Küreselleşme süreci, ulus-devletlerin yetkilerinin bir kısmını yerel yönetimlere bir kısmını da Uluslararası örgütlere devretmesine yönelik çalışmalar başlatmıştır (Keyman vd.,2015:27).

Böylece, küreselleşme süreci bölgeselleşme sürecini de desteklemeye başlamış ve kendi için farklı katmanlarda birden çok alt süreci kapsamıştır. Üç önemli bölgesel yapılanmadan bahsedebiliriz.

1. Bölgesel Diyalog

Güney Asya ve Pasifik ülkeleri arasındaki Asya-Pasifik Ekonomik İş birliği (APEC). Karşıllklı ticaret temelli bir ilişkidir.

2. Bölgesel İş birliği

A.B.D., Kanada ve Meksika arasındaki ticaret iş birliği. Kuzey Amerika Serbest Ticaret Birliği (NAFTA)

3. Bölgesel Bütünleşme

En derin ve bölgesel yapılanma olarak bilinen Bölgesel bütünleşmeye Avrupa Birliği (AB) örnek olarak verilebilir.

Üçünün ortak noktası hepsinin karşı1ıklı kazanca dayalı ağlar yaratarak ekonomik alanda ve ticaret ilişkilerinde serbestleştirme getirmesidir. Aralarındaki ayrım ise bu iş birliğinin hukuksal ve siyasal anlamda ne kadar güçlü ve derin olmasıdır. Dünya ekonomisinin küreselleşmesi, uluslararası ticaretin önünde nerdeyse hiçbir engel kalmadığı anlamına gelmektedir (Burchill ve Linklater, 2015:121).

Uluslararası Para Fonu (International Monatary Fund - IMF) nun küreselleşmeye ilişkin tanımında teknolojinin ve buluşların hızlı bir şekilde geniş bir alana yayılması ile dünya çapında ülkeler arasındaki artan bağımlılı̆̆ ayn zamanda da ekonomilerin özellikle de mali ve ticari kaynaklı artan bütünleşmesini ifade edilmektedir. (Özerkmen, 2004:135).

Devlet Planlama Teşkilatı (DPT)'nin Sekizinci Beş Yıllık Kalkınma Planının Küreselleşme ile ilgili bölümünde ise; ulusal sınırların aşılarak siyasi, ekonomik, sosyal ve kültürel değerlerin dünyanın geneline yayılması olarak tanımlanmıştır (DPT, 2000:3).

Dünya Ticaret Örgütü (World Trade Organization - WTO)'nun tanıma göre ise de küreselleşme teknolojideki son gelişmelerin kapitalizmin hızla genişlemesinin tarihsel evrimi olarak toplumsal güçleri ve ekonomiyi yeni bölgelere yayarak toplumları temel olarak dönüştürmektir. 2005 ve 2013 yılları arasında, 30 Ocak 2006 yılında Şili'de, WTO'da üst düzey yöneticiliği yürütmüş olan Pascal Lamy gerçekleştirmiş olduğu toplantıda "Günümüzdeki küreselleşmenin ve yükselen serbest pazarın artık negatif neticelerinden daha çok pozitif neticelerinden söz ediyoruz" demiştir (WTO, 2006).

OECD’nin küreselleşme tanımında ise, küreselleşmenin yarattı̆̆ 1 yaygınlaşma, derinleşme ve hızlanmanın yalnızca iletişim ve bilişim alanlarıyla sınırlı olmadığını ve küreselleşmenin ticaret ve finans ilişkileri temelinde ekonomik alanda da güçlü olduğunu büyük sanayileşmiş devletlerin oluşturduğu Ekonomik İş birliği ve Gelişme Örgütü’nün (OECD) küreselleşme tanımına bakarak anlayabiliriz. OECD küreselleşmeyi, değişik ülkelerdeki piyasaların ve üretimin, ürün ve hizmet sunumlarıyla teknoloji ve sermayenin hareketliliği ile birlikte devamlı birbirine bağımlı hale geldiği bir süreç olarak tanımlamakta ve bu tanımıyla da küreselleşmenin iç içe geçme ve yoğunlaşma halini anlatmaktadır (Kardaş ve Balcı, 2017:510). 
Sosyologların yaptıkları küreselleşme tanımlarına bakıldığı zaman, toplumlar arası sosyal ilişkilerin yoğunlaşması üzerinde durulmaktadır. Bu yoğunlaşma süreci farklı kültürlere sahip uzak bölgeleri bile birbirine bağlamakta, yerel olarak yaşanan olaylar diğer bölgelerde yaşanan olaylardan etkilenir hale gelmektedir. Kültürel ve sosyal düzenlemeler üzerindeki coğrafi engellerin giderek ortadan kalktığı ve insanların da bu değiş̧imleri kabullendiği bir süreç olarak küreselleşme tanımlanabilmektedir. Bu da dünyadaki örgüt ve kültürlerin, insanların birbirine bağlanmasıdır (Özalp ve Kırel, 2001:18).

Amerikan Ulusal Savunma Enstitüsü küreselleşmeyi "teknolojinin, hizmetlerin, ekonominin, düşüncelerin, enformasyonun, kültürün ve halkların sürekli ve hızlı bir biçimde sınır dışına sürüp gitme" şeklinde tanımlamaktadır. Söz konusu enstitünün yaptığı bir çalışmaya göre küreselleşme sayesinde enformasyon devrimi yaşanırcasına ülkelerin ekonomileri arasında daha önce görülmemiş bir bütünleşme temin edilmiş olup, örgütler, firmalar, pazarlar ve yönetim uluslararası hale gelmektedir (Öymen, 2000:26).

Küreselleşmenin ekonomik yönünün etkileri sonucu insanların sosyal hayatında da birtakım değişimler olmuştur ve bunlar da küreselleşme kavramı ile açıklanmaya çalışılmıştır. Küreselleşme kavramı bazen dünya toplumlarındaki değişim süreçlerini, buna bağlı olarak da dünya çapında kültürün ortaya çıkmasını; bazen de toplulukların ve kimliklerin kendi farklılıklarını ifade etme ve tanımlama sürecinde kullanılabilmektedir (Keyman ve Sarıbay, 1998:26).

\subsection{Küreselleşmenin Tarihsel Süreci}

İlk olarak küreselleşme kavramının W.Foster'in (İngiliz Ekonomist) 1833'de yazdığı dünya üzerindeki kaynakların kullanımı ve dağılımı konulu bir makalede kullanılmış olduğu, ilerleyen yıllar içerisinde The Economist dergisinde 4 Nisan 1959 tarihinde yer aldığ bilinmektedir. Ancak, küreselleşmenin günümüzde yaygınlaşması ile Garett Hardin'in 1968 yılında yazmış olduğu kaynakların ne şekilde kullanılması ve paylaşılması hususundaki çalışmasına dayandığı belirtilmektedir. (Kıvılcım, 2013:221).

Küreselleşme kavramı 1980'li yılardan sonra dünyada her ne kadar yoğun bir sekilde ele alınsa da olayın ortaya çıkışı çok daha eski yıllara kadar uzanmaktadır. Hatta R. Robertson'un yaptı̆̆ı bir analize göre küreselleşme olgusu 15. Yüzyıla kadar gitmekte ve bunu 5 aşamalı olarak incelemiştir. Bu süreçler; oluşum aşaması, başlangıç aşaması, kalkış aşaması, sömürgecilik diğer bir deyişle hakimiyet için mücadele aşaması ve Belirsizlik aşamasıdır. Ancak söz konusu değerlendirme, siyasal faktörler göz önüne alınarak yapılmıştır (Kaya ve Aydemir, 2011:15).

Küreselleşmenin oluşum aşamasında ulus topluluklar yavaş yavaş ortaya çıktı ve Ortaçağ'ın ulus ötesi sisteminin çökmesiyle birlikte batı kilisesinin (Katolik kilisesi) etkinlik alanı genişledi. Dolayısıyla, insanlık ile ilgili düşünceler birey anlayışları olarak öne plana çıktı. Başlangıç aşamasında devletin bölünmez bir bütün olarak kabul edildiği üniter devletler düşüncesi doğrultusunda önemli değişiklikler meydana geldi. Buna göre, resmi uluslararası ilişkiler anlayışı gelişti, birey bilinci oluşarak daha somut bir insanlık anlayışı yerleşmiş olup, bu konularda Uluslararası ve ulus ötesi düzenlemeler ve iletişime ilişkin yasal sözleşmeler yapılmıştır. Kalkış aşamasında ise "modernlik" sorunu ilk kez özgünleşmeye başladi.

Robertson'un küreselleşmenin dördüncü evresi olarak tanımladığı sömürgecilik diğer bir deyişle hakimiyet için mücadele aşaması 1920'lerin ortalarında başlayarak 1960'lı yıların sonuna kadar sürdü. $\mathrm{Bu}$ süreçte, Birleşmiş Milletler'in kurulmasının ardından Ulusal bağımsızlık ilkesi kabul edildi ve Üçüncü Dünya belirginleşmeye başladı. Robertson, küreselleşmenin beşinci aşaması olarak tanımladığı "belirsizlik aşaması" ise 1960'lı yılların sonunda başladı ancak, 1990'lı yılların başında krize girdi. Bu evrede "hak ve özgürlükler" temasının öne çıkmaya başlaması ile soğuk savaş dönemi sona erdi. Küresel kurum ve hareketleri çoğalarak kitle iletişim araçlarının yaygınlığı, hızı ve sayısı önemli derecede arttı (Kürkçü, 2013-04:4-5). 
Küreselleşme sürecinin hız kazanmasında sanayi devrimi ile otomasyon ağının gelişmesi çok etkili olmuştur. İki önemli dünya savaşı ve yaşanan ABD-SSCB rekabeti insanlığ 1 çok tehlikeli bir noktaya getirmiştir. Söz konusu bloklar arasında gerilimin azaltılması için "güç"ün yerine "kuralların" istenilen sonucu verecek niteliğe dönüşmesi gerektiği gerçeği kendini hissettirmiştir. Bu normun ortaya çıkış noktası ise AGIKK (Avrupa Güvenlik ve İş birliği Konferans1) düşüncesi olmuştur. Temel diplomatik, aynı zamanda Helsinki son senedi olarak da bilinen anlaşma ile dönemin iki süper gücü arasında ekonomi, güvenlik, enerji, ticaret ve insani gibi hususlarda mutabakata varılmıştır. Daha sonra 1977-78 yıllarında Belgrad, 1980-83 y1llarında Madrid, 1986-89 y1llarında Viyana ve 1990 yılında Paris zirveleri gerçekleşmesine müteakip, 1990 yılında Kopenhag, 1991yılında Moskova İnsani Boyut Konularının Uluslararası Niteliği, 1994 yılında Brüksel, Viyana Güven Artırıcı Önlemler ve Helsinki zirveleriyle de küreselleşme sürecine yeni gelişmeler kaydedilmiştir.

AGIT'in son olarak 1996 Lizbon ve 1999 İstanbul zirveleri sonucunda "sınır tanımayan insan hakları" kavramının gündeme gelmesi çabaları sonucunda 2000'li yıllarda "insan hakları ve demokrasi" çerçevesinde daha uyumlu bir dünyanın yaratılmasına önemli katkılar sağlamıştır. (DPT, 2000:50).

Dolayısıyla, yukarıda açıklanan tarihsel gelişim sürecinde siyasi bir haritada, ülkeler arasındaki sınırlar her zamanki gibi net iken, rekabetçi bir haritada, diğer bir deyişle, finansal ve endüstriyel faaliyetlerin gerçek akışlarını gösteren bir harita üzerinde, bu sınırlar büyük ölçüde ortadan kalkmıştır (Harward Business Review,1989).

\section{Küreselleşmenin Boyutları}

\subsection{Küreselleşmenin Askeri Boyutu}

Küreselleşmenin önemli boyutlarından birisi de hiç kuşkusuz Askeri Yönü'dür. Soğuk Savaş (Cold War) sonrasında uluslararası ilişkileri askeri yapıdan arındırmak için yeni ve ciddi bir bakış açısını geliştirme zorunluluğunu ortaya çıkarmıştır. Çünkü ABD ve SSCB arasındaki rekabet askeri harcamaları besleyerek yeni silahların gelişmesine ve sorunların sadece askeri çözümler bulunmasına yol açmıştır. Bu perspektiften baktığımızda savunma harcamaları ve buna dahil barışı koruma ve insani yardım için yapılan harcamalar da göz önüne alındığında NATO küresel çok uluslu bir yapıdır (NATO,2019).

NATO üyesi ülkeler arasında İttifak Operasyonlarına katkılar bakımından Türkiye'nin de ön sıralarda yer alması da büyük önem arz etmektedir. Askeri küreselleşme, David Held tarafından dünya sisteminin siyasi birimleri arasındaki askeri ilişkilerin artan yaygınlığını ve yoğunluğunu bünyesinde barındıran süreç olarak tanımlanmaktadır. Bu şekilde anlaşıldığında, hem dünya çapındaki askeri bağların ve ilişkilerin genişleyen ağını hem de zamanla dünyayı tek bir jeostratejik uzayda yeniden oluşturan önemli askeri teknolojik yeniliklerin (buharlı gemilerden uydulara) etkisini yansitıyor. Askeri küreselleşme, dünya çapındaki silahlı kuvvetlerin küresel askeri sisteme daha sıkı entegrasyonu anlamına gelir.Robert Keohane ve Joseph Nye için ise askeri küreselleşme, kuvvetin ve kuvvet tehdidinin veya vaatlerinin kullanıldığı uzun mesafeli karşılıklı bağımlılı ağlarını gerektirdiğini vurgulamışlardır.(https://en.wikipedia.org/wiki/Military_globalization, 2020).

Küresel uyumun sağlanması bakımından, Doğu Avrupa ülkelerini içine alarak genişlemesi NATO'nun kendisine önemli sorumluluklar yüklemektedir. İstikrar ve barışın korunması ve geliştirilmesi için askeri örgüt niteliğindeki NATO üyeleri daha fazla çaba göstermek durumundadırlar (DPT,2000:51).

\subsection{Küreselleşmenin İletişimle İlgili Boyutu}

İletişim alanında yaşanan devrim küreselleşme sürecini hızlandıran en önemli unsurlardan biri olmuştur. 20.yüzyılın son çeyreğinde iletişimde yaşanan köklü ve nitelikli değişimde fiber optik kablo bağlantılarının ve uydu yayınlarının büyük rolü olmuştur. Bilgisayar kapasitelerindeki bu artış da insanoğlunun veri işleme ve saklama kapasitesini gözle görünür biçimde artırarak bilgisayarı, hükümetlerin, iş yerlerinin ve hanelerin kullanımına hazır hale getirmiştir. 
Bireyler açısından bakarsak, bir yatırımcının fonlarını almak veya satmak için bir aracıya ihtiyacı artık yoktur. Bunun yerine evinin rahat ortamında internet üzerinden finansal işlemler gerçekleştirilebilir. (Viotti ve Kauppi, 2014a:150).

Ayrıca, dünyanın dört bir yanındaki idarecilerin ve pazarlama yöneticilerinin katılabildiği toplantılara imkân veren görüntülü telekonferans yıllardır büyük şirketlerin kullandığı bir yöntemdir. Dolayısıyla, bu gelişmeler büyük miktarda işin dünyanın dört bir yanına dağılarak coğrafi uzaklıkların anlamsızlaşmasına neden olmuştur. Örneğin, biri Washington DC' de diğeri Colorado ve Hawaii'de yaşayan iki profesör, uluslararası ilişkiler kitabı üzerinde çalışabilir. (Viotti ve Kauppi, 2014b:151).

\subsection{Küreselleşmenin Ekonomik Boyutu}

Küreselleşmenin diğer önemli bileşenlerinden birisi de ekonomik boyutudur. Bu bağlamda, günümüz uluslararası ticaretinin kendine özgü nitelikleri ekonomik küreselleşmenin önemli bileşeni olmuştur. $\mathrm{Bu}$ çerçevede bir örnek olarak, II. Dünya Savaşından sonraki dönemde, Dünya Gayrisafi Yurtiçi Hâsılasının (GSYIH) 6 kat artmasına rağmen, dünyadaki ticari eşya ihracatı 20 kat arttmıştır (Dağ, 2020).

Çağdaş küreselleşme olgusu örneğinde ekonomik karşılıklı bağlanmışlık ve karşılıklı bağımlılık ağları, dünya ekonomisinin ilk kez tek bir küresel varlık olarak algılanmasını mümkün hale getirecek şekilde genişlemiştir. (Heywood,2016b:130). Ekonomik olarak birbirine ihtiyaç duyan ülkeler giderek artmaktadır. Küresel ekonominin en önemli özellikleri sınırsız, görünmez ve siber bağlantılı bir yapıdır. Küresel ekonomi artık sınırsızlığın olmadığı bir dünyaya dayanmaktadır (Ohmae, K.2007:20-24). 21.yüzyıl ilerledikçe, açıkça ütopik bir niyet olan sınırsız bir dünya gerçekleşmiş durumdadır (Mbembe, A. 2018).

Mal ve hizmetlerin üretimi, değişimi ve tüketimiyle ilgilenen ekonomik alandan birkaç örnek aşağida yer almaktadır:

- Çok uluslu şirketler, herhangi bir ülkeden çok, tabiiyetleri ne olursa olsun hissedarlara ve diğer ilgili taraflara yakındır. Artık gerçek anlamda çok uluslu bir iş gücü varken, o şirkete" Amerikan" veya "Fransız" demek gittikçe anlamsızlaşmıştır.

- Bir ülkenin dünya piyasalarına ticaret yoluyla katılımı anlamına gelen ticari bütünleşme, geçtiğimiz yıllar boyunca düzenli olarak artarak yüzde 30'dan az iken yüzde 50'den fazlaya gelmiştir. Aynı zamanda Kuzey Amerika Serbest Ticaret Anlaşması (NAFTA) gibi bölgesel anlaşmalar da artmıştır.

- Ekonomik entegrasyonun artmasında dolayı bir ülkedeki finansal sorunlar bir bölgenin tamamında ya da tüm dünyada sarsıntıya yol açabilir.

Dolayısıyla, küresel ekonomi alanında çok uluslu şirketler uzun zamandır önemli oyuncular olagelmiştir (Viotti ve Kauppi, 2014, s.15).

\subsection{Küreselleşmenin Siyasi Boyutu}

Günümüzde siyasi güç, yönetim ve otorite biçimlerindeki yapısal dönüşüm olarak siyasi küreselleşme tanımlanabilir. Bugün küresel siyasetin etki alanının tüm dünya tarafından kabul edildiği anlayışının giderek yaygınlaştığ 1 görülmektedir. Bu da bize küreselleşmenin geleneksel devlete ve siyasete ilişkin yaklaşımlardan farklı bir yapıyı yansıttığını belirtmektedir. Diğer bir deyişle, "Dünya çapında siyaset", söz konusu yapının dört temel aktörü olan ulus devlet, devletler-üstü kurumlar, sivil toplum ve yerel yönetimlerin karş1lıklı etkileşimi sonucunda şekillenmektedir.

Küreselleşme ile birlikte demokrasi, özgürlük, insan hakları, çevrenin korunması gibi temel değerler evrensel nitelik kazanırken, ulus-devlet de demokratikleşme, yerelleşme, esneklik, katılım, şeffaflık gibi güçlü eğilimlerin yoğun baskısı altında yeniden biçimlenmeye zorlanmaktadır. Bu çerçevede, ülkelerin temel politikaları oluşturulurken kamu yönetiminin küçülmesi, yasal düzenlemelerin gerçekleştirilmesi, ekonomik değişimlerin toplum üzerindeki etkilerini inceleyen sosyo-ekonomik politikaların dönüşümü gibi stratejiler büyük önem arz etmektedir (Kıvılcım, 2013:226).

Günümüzde terörizm faaliyetlerini planlama ve harekete geçme aşamalarında teknolojiden efektif şekilde faydalanarak uluslararası ortamda çok daha hızı bir biçimde hareket ederek daha ağır sonuçlar yaratma girişimine girebilmektedirler (Dağ, 2020:7). 


\subsection{Küreselleşmenin Çevresel/Demografik Boyutu}

Küreselleşmeyle birlikte çevre konusu, özellikle 1990'lı yılların başlarından itibaren en önemli konulardan biri haline gelmiştir. Küresel 1sınma, kuraklık ve sel felaketleri, hava kirliliği, nükleer ve kimyasal atıklar gibi problemler küreselleşme süreci ile bağlantılıdır. Bu sorunların küresel ölçekte sonuçlar doğurmaları büyük önem arz etmektedir. Şöyle ki; çevre sorunları, uluslararası karşılıklı bağımlılı̆̆ın bir örneği olup, genellikle ilgili devletler açısından ortak fayda sorunları yaratması ve küresel çevre sorunlarına çok aktörün taraf olması bu sorunların çözümünü zorlaştırmaktadır. Dolayısıyla, çevre sorunlarının çözümü konusundaki uluslararası çabaların amacı, sürdürülebilir bir ekonomik kalkınma sağlamaktır (Goldstein ve Pevehouse, 2015:532).

Şu anda 7 milyar olan dünya nüfusu yakında 10 milyarı bulabilir. Bu artışın neredeyse tamamı Küresel Güney'den kaynaklanacaktır. Dünya nüfusunun gelecekteki artışını, büyük ölçüde demografik geçiş yönlendirecektir. Yoksul ülkelerin ekonomileri ne kadar hızlı gelişirse, nüfusları o kadar çabuk dengelenecektir (Goldstein ve Pevehouse, 2015:533).

\subsection{Küreselleşmenin Sosyokültürel Boyutu}

Uluslararası ilişkiler ve dünya siyaseti konusunda bazı gözlemcilere göre küreselleşmenin esas boyutu ekonomik değil sosyokültürel boyutudur. Söz konusu boyutun en bariz örneği, sosyal paylaşım sitesi olan facebook'tur. Facebook 800 milyon aktif kullanıcıya ve kırk milyar fotoğrafa ev sahipliği yapmaktadır (Viotti ve Kauppi, 2014:155).

Bu sayede, söz konusu toplumlar ve bireyler arasında daha önceden birbirlerine yabancı gelen yaşam tarzları temelinde ortak bir payda oluşturarak farklı zevkler, ilgi alanları gibi konularda belirli bir ahenk, hatta tekdüzelik sağlanmakta olup, bir anlamda da dünya çapında bir kültür ve birikim ortaya çıkmaktadır.

Özellikle, yaşam biçimi olarak adlandırılan, giyim, müzik, eğlence yiyecek ve içecek tercihlerimiz ile tüketim eğilimlerimiz için küresel kültür, dünya ölçeğinde bir benzeşme ve standartlaşma anlamına gelmektedir (Keyman vd., 2015:43). 1990'lı yılların küresel eğilimleri küreselleşmenin bu çoklu bağlantıları nedeniyle, Kanada'lı yazar Marshall Mc.Luhan ile anılan bir kavram olan küresel köy metaforu dünya sisteminin, ekonominin ve siyasetin ötesinde bağlantılı olduğunu ihsas etmektedir. Bu bağlantı ile artık sınırların zorlanarak belirginliğini yitirmeye başladığı ifade edilmektedir (Konukcu, 2018:2017).

\section{Küreselleşmenin Havayolu İşletmelerine Etkileri}

Bilindiği gibi, Havayolu taşımacılığı, sosyal, kültürel, ekonomik ve politik süreçlere önemli katkıları olan aynı zamanda da bir bölgenin özellikle turizm gibi belirli bir endüstrinin ekonomik kalkınmasına katkıda bulunan önemli bir sektördür. (Ion D.C..2011). Küreselleşme ile birlikte karmaşıklaşan sistematik birimler ve bu birimlerin koordineli çalışmasını sağlayacak ünitelere ihtiyaç duyulmuş ve bunun sonucunda sektör dediğimiz ortak birimler ortaya çıkmıştır. Bu sektörlerden en karmaşık ve yüksek teknoloji gerektireni ise havacılık sektörü olmuştur.

Küreselleşmenin birçok ortaya çıkış etkileri, küresel pazarlardaki talebin ölçeği, doğası ve coğrafyasının yol açtığı yalnızca talep tarafında değil, uluslararası hava taşımacıllğı sektörü için de yoğun olmuştur. Küreselleşme kaçınılmaz olarak, modern hava taşımacılığının büyük ölçüde ticari yönelimi göz önüne alındığında, ek arz getirecek olan ülkeler arasında insanların ve kargoların dolaşımı için daha yüksek talepler anlamına gelmektedir (Button, K.2008).

Dünyanın tek bir pazar olarak kabul edilmesi, genel ekonomik durumu canlandıracak yeni teknolojilerin gelişimi ve yüksek rekabet koşulları dünya pazarlarında sektörler ve işletmeleri evrim geçirmeye zorlamış ve değişim ile yenilikleri kabul edenler varlıklarını sürdürmüş diğerleri küresel dünyada yok olup gitmişlerdir. Havayolu taşımacılık sektörü ve havayolu işletmeleri için de küreselleşmenin evriminde önemli bir faktör olmuştur.

$\mathrm{Bu}$ nedenle kendilerini yenileyen bu işletmeler, yeni pazarlara ve küresel ölçekte oluşumlara girme ihtiyacı duymaya başlamışlardır. Ancak küresel ölçekte iş yapabilmek için öncelikle havayolu 
işletmesinin uluslararası sivil havacılık kurallarını yerine getirmesi gerekmektedir. Havayolları için böyle bir gelişmenin sağlayacağı önemli avantajların başında pazar konumunun güçlendirilmesi, ağ genişletilmesi, ürün entegrasyonu, marka sadakati ve maliyetlerin azaltılması gibi konular gelmektedir. (Ion D.C.2011).

Küresel bir havayolu işletmesinin diğer bir özelliği ise, küresel ölçekte dağıtım kanallarına sahip olmasıdır. Dağıtım kanalı müşterilerin havayolu hizmet sunumu hakkında bilgi elde edebilmelerine ve bu hizmeti satın alabilmelerine olanak tanımaktadır. Küresel dağıtım kanallarına sahip olmayan bir havayolu işletmesi, doğal olarak küresel üretimine müşteri de bulamayacaktır.

Küreselleşme ile ileri teknoloji kullanılmakta ve ileri teknoloji ürünlerin kullanımı hızla artmaktadır. Küreselleşmenin artması ve küresel dünyada tüm kullanıcılara ulaşabilmek ve bunu da maliyet kontrolü ile yapabilmek için internet en iyi yol olarak karşımıza çıkmaktadır. Dünyanın her bölgesinde müşteriler kendi dilleri ile havayolu işletmesinin web sayfasına girebilir ve istediği hizmeti zaman kaybetmeden satın alabilirler. Günümüzde birçok havayolu işletmesi web sitesi üzerinden satış yapmaktadır. Web sitesi üzerinden havayolu işletmeleri tüm bilgileri müşterilerine sunarak daha hızlı ve etkin bir alışveriş̧ olanağ 1 tanımaktadır. Havayolu işletmeleri e- ticareti teşvik ve yolcu bağl1lığ 1 yaratmak için internet üzerinde yolcu kayıtları tutmaktadır ve bu kayıtlar ile zaman içerisinde yolcularına indirimli bilet kullanma hakkı veya açık bilet hakkı vermektedirler (Berardino vd., 2000:459).

Küreselleşme ile birlikte işletmelerin faaliyet gösterdiği çevre çok daha karmaşıklaşmıştır. Bunun sonucunda havayolu işletmeleri artık dünyanın her yanındaki rakipleri ile ilgili bilgi toplamak, farklı ülkeler ile ilgili potansiyel bilgilere sahip olmak, talep analizleri yapmak ve teknolojinin baş döndürücü hızına ayak uydurmak durumundadırlar.

20.yüzyılın sonlarına doğru işletmeler birçok farklı koşullarla baş etmek durumunda kalmışlardır. Sürekli değişen çevre koşulları, ekonomik sistemin dinamik yapısı, sosyal sistemlerdeki değişimler ve teknolojik gelişmeler işletmeleri değişimin ve gelişimin içine sürüklemişlerdir. Sosyal yapılardaki evrim endüstriyel kültürlerin de parçalanmasına neden olmuştur. Ekonomik evrim ise insanların yaşamlarındaki değişime ve tüketimin temelden artmasına neden olmuştur. Teknolojide evrim ise endüstriyel oluşumlardan bilgi oluşumlarına doğru bir sürüklenme oluşturmuştur. $\mathrm{Bu}$ da küreselleşen dünyada yeni bir organizasyona doğru yola çıkılması gerekliliğini doğurmuştur. ICAO ve IATA, bu anlamda sektörü yönlendiren en etkin düzenleyici kuruluşların başında yer almaktadırlar. Havayolu işletmeleri ise, stratejilerini ve rekabet araçlarını bu organizasyonların politikalarına göre değiştirmektedir. Dolayısıyla sektör, bu gelişmelere paralel olarak giderek daha karmaşık, dinamik ve belirsiz bir çevre tarafından kuşatılırken ekonomik düzenlemelerin etkilerini anlamak çok daha önemli hale gelmektedir.

$\mathrm{Bu}$ tüm değişim bloğu ile başa çıkabilmek için işletmeler birçok yeni yönetim stratejileri ortaya koymuşlardır. Stratejik ittifaklar ve iş birlikleri de bu yöntemlerden birisidir. (Wang ve Evans, 2002:73).

11 Eylül sonrası krizden bağımsız olarak, dünya çapında hava taşımacılığı endüstrisi son 25 yılda çarpıcı değişiklikler yaşadı. Belki de en kapsamlı olanı, en büyükler arasında birleşmeler, satın almalar ve / veya stratejik ittifaklarla sonuçlanan liberalizasyon veya deregülasyon politikalarının bir sonucu olarak, uzun süredir yerleşik düzenleyici rejimlerin değiştirildiği ve bazı durumlarda kaldırıldığı kurumsal ortamda meydana geldi.

Havayolu stratejik ittifaklarının ve yeniden ağ yapılandırmasının, havayolu endüstrisindeki küreselleşme süreçlerinin en güçlü tezahürü olduğu iddia edilebilir. Buna ek olarak, küresel navlun ticaretinin yaklaşık \%40'ının hava yoluyla gerçekleştirildiği de tahmin edilmektedir (Goetz A.R., vd.2004:265-276)

Küresel havayolu ittifakları, bu süreçlerin hem ürünü hem de devamı için katalizör görevi göreceği tahmin edilmekteydi. Bu gelişmeler, havayolu işletmelerini küresel bir ölçekte faaliyet göstermeye, bunun için küresel pazarlara erişmeye ve girmeye zorlamaktadır.

Havayolu işletmeleri artık girdilerini küresel bir ölçekten toplayıp, taşımacılık hizmeti üretim süreçlerini küresel bir ölçekte gerçekleştirip çıktılarını küresel bir ölçeğe sunmak zorunda kalmaktadır (Gerede, 2017:141) 


\section{Küresel Havayolu İttifakları}

Havayolu ittifaklarının doğuşu, tarihsel olarak, dağıtım merkezi planının gelişimi ve havayollarının uluslararası ve yerel ağlar kurma ihtiyacıyla bağlantılıdır. ABD'deki büyük havayolu taşıyıcıları, daha büyük ve daha karlı orta ve uzun mesafeli ağlarını desteklemek için daha uygun maliyetli bölgesel taşıyıcılarla kod paylaşımları oluşturarak bölgesel ittifakları başlatmışlardır. (Garcia, A.T. 2012)

Tarihsel süreçte, küresel havayolu ittifakları, IATA'nın öncelikli olarak uluslararası uçak biletlerini koordine etmek için kurulduğu 1945 yılına kadar dayandığı bilinmektedir (Garcia, A.T.,2012). Uluslararası havayolu taşımacılığının kademeli olarak liberalleşme eğilimleri ABD tarafından 1978'de ulusal serbestleşmesini gerçekleştirmesi ve 1979'da Uluslararası Hava Taşımacıllı̆ı Rekabet Yasası ( International Air Transportation Competition Act of 1979 ( IATCA, 1979 ) ardindan ikili havayolu taşımacılığı anlaşmalarını müzakere etmeye başlamıştır (Wang ve Evans, 2002:28).

ABD ikili liberalleşme eğilimlerini 1978'de Hollanda ile imzaladığı anlaşma ile başlatmıştır. Buradaki amaç, Hollanda gibi yüzölçümleri küçük, nüfusları az olan ülkelere pazardan daha fazla faydalanma hakk1 vermekti. Daha sonraki aşamada ise ABD'nin liberalleşme politikalarını genişleterek Kuzey ve Orta Pasifik pazarına doğru Tayvan, Güney Kore, Tayland, Singapur ve Japonya gibi ülkeler arasındaki pazarları daha liberal hale getirmiştir. (Gerede, 2015:104).

İlk uluslararası havayolu ittifakı 1986 yılında Air Florida ve British Island arasında kuruldu. İttifak oluşumunun başlıca katalizörü olan 1978'de ABD'deki serbestleștirilmenin ardından küresel olarak birbirini izleyen deregülasyon hareketleriydi. 1997'de Star Alliance'in oluşturulması ve sırasıyla 1998 ve 2000'de Oneworld ve SkyTeam'in kurulması önceki ittifak uygulamasından farklı bir noktaya işaret etti. Bu ittifaklar, kod paylaşımı, ikili anlaşmalar ve bölgesel ittifaklar gibi geleneksel ortaklık yöntemlerinden küresel ağlar ve ortak bir strateji oluşturma yönünde stratejik bir sıçrama yaptı (Blancing, D., 2009).

İttifaklara geçişte en önemli hususlardan birisi İkili havayolu hizmet anlaşmalarındaki mülkiyet yasaları ve ulusallık maddeleri sınır ötesi birleşme ve kazanımları önlemesi olmuştur. Uluslararası trafiğgin yerel trafikten daha hızlı artması nedeniyle, hava yolları stratejik ittifaklar yoluyla korumacı yasalardan kurtulabilmektedirler. Bu ortaklıkların yaygın olan ortak özelliği kod paylaşımıdır (Önen,2018:103).

Teknik olarak, kod paylaşımı, iki taşıyıcı arasında, birbirlerinin uçuşlarında kendi belirleyici kodları altında koltuk satmalarına izin veren bir düzenlemedir. İki veya daha fazla kod paylaşımlı taşıyıcının bağlantılı uçuşları durumunda, yolcunun tüm uçuşu bir CRS'de (Bilgisayar Rezervasyon Sistemleri) tek bir taşıyıcı hizmeti olarak görüntülenir. Söz konusu sistem taşıyıcılar ve potansiyel yolcular arasındaki arayüzü sağlar. Havayolları, ortak trafik akışlarını teşvik etmek için CRS sistemleri tarafından sağlanan bilgi kanallarını kullanmak için birleşir ve kod paylaşımını içerir (Button, K., 1997).

Küresel ittifakların havayolları ve yolcular için en büyük yararlarından birisi de genişletilmiş ve optimize edilmiş bir rota ağıdır. Küresel ittifaklar aracılığıyla, yolcular, teorik olarak, bir havayolunun biletiyle dünyanın herhangi bir yerinden diğerine kolayca seyahat edebilmektedirler. Küresel havayolu ittifaklarının dünya çapında kapsama alanı sunan etkili hub ve bağlı sistemlerin yaratılmasıyla sağlanan ittifak rotalarında trafikte önemli bir artışa (ortalama\%9,4) yol açtığı görülmektedir.

Yukarıda belirtilen küresel bir ağa erişim sağlamanın dışında, daha hızlı transfer süreleri ile transfer sürelerinde iyileşme sağlandığı görülmektedir. Örneğin, daha hızlı aktarım süreleri elde etmek için Star Alliance stratejisi olan Move Under One Roof, Japonya'nın Narita kentinde bekleme sürelerini \%50 azaltmıştır. Bu azalma, tüm üye havayollarının aynı terminalde gruplanmasıyla sağlanmıştır.

Bunların yanısıra, kesintisiz bağlantılar ittifakların, ne kadar uçuş değişikliği yapmaları gerektiğine bakılmaksızın, yolcular ve bagajları için "tek noktadan kontrol" sağlama becerisi göstermektedir (Blancing, D.,2009). 
Daha önce de belirtilen 1986 yılında Air Florida ve British Island arasındaki ilk ittifakın ardından sırasıyla, 1988 yılında KLM ve Northwest Airlines 1989 y1lında Swissair ve Delta Airlines arasında ittifaklar kuruldu. 1990'ların başında, Kuzey Atlantik'teki diğer ikili stratejik ittifaklar ise British Airways-US Airways ve United Airlines- Lufthansa arasında kurulmuştur (Garcia, A.T., 2012).

Günümüzde 3 büyük küresel ittifak dünyadaki yolcu trafiğinin yaklaş1k\%55'ini oluşturmaktadır. Şöyleki; 2018'de Star Alliance havayolu ittifakı, pazar payının \%21,7'sini oluşturan lider havayolu ittifakıydı, onu \%16,1 ile SkyTeam ve \%15,6 pazar payı ile Oneworld izledi. 14 Mayıs 1997'de kurulan Star Alliance'ın şu anda merkezi Almanya'da Frankfurt'da bulunmaktadır. İttifakın sloganı: "Dünyanın Bağlandığı Yol" olup önde gelen havayolu üyeleri arasında Türk Hava Yolları, Lufthansa, Singapur Hava Yolları, Air China, Air Canada ve United Airlines yer almaktadır (Airline Alliances Statistics).

1 Şubat 1999'da kurulan Oneworld havayolu ittifakının merkezi New York'dadır. 2017 yılında yaklaşık 6,7 milyar ABD doları net kar elde eden üye havayolları arasında şunlar yer alıyor: American Airlines, British Airways, Japan Airlines, Malaysia Airlines, Finnair, Iberia, Qatar Airways, Royal Jordanian, Sri Lanka ve Sloganı da "Dünyanın lider tek ittifakı" olarak ifade edilmiştir.

Haziran 2000'de kurulan SkyTeam ise, üç büyük havayolu ittifakının sonuncusudur. SkyTeam 2018'de yaklaşık 9,5 milyar ABD doları işletme karı elde etti. SkyTeam şu anda "Sizi daha çok önemsiyorum" sloganıyla faaliyet göstermektedir ve merkezi yönetim ekibi SkyTeam Central, şu anda Hollanda Haarlemmermeer'deki Amsterdam Schiphol Havaalanı yakınında bulunmaktadır. 2018'de SkyTeam'in geliri yaklaşık 152,9 milyar ABD doları olarak gerçekleşti. SkyTeam'in kod paylaşım sayısına göre önde gelen havayolu üyeleri şunlardır: AirFrance, KLM, Korean Air, Alitalia, China Eastern Airlines ve Aeroflot havayoludur (Airline Alliances Statistics).

Küresel pazarlara erişim konusunda Star Alliance üyesi THY (Türk Hava Yolları) örnek olarak verilebilir. THY'nin geçmiş altyapısı ve deneyimlerini küresel pazarlarda kullanmak amacıyla küreselleşme stratejisi izleyerek başarılı olduğu düşünülmektedir. Diğer bir deyişle, THY'nin küresel büyümenin avantajlarından yararlandığ 1 söylenebilir. Küresel nitelikli Star Alliance grubuna kendi kaynaklarını kullanarak katılan THY uçuş ağını genişleterek, büyütmüş ve bu nedenle coğrafi avantajını da kullanarak transit yolcu sayısını artırmıştır. Söz konusu bu durum, ülkemizin yaratmadığı bir talebi bularak, taşıyarak birim gelirleri artıran, birim giderleri düşüren küresel ölçekte rekabetçi üstünlük getiren bir gelişme olarak değerlendirilmektedir (Gerede,2015:105-106).

THY Topla ve Dağıt (Hub and Spoke) uçuş ağı sistemini uygulayarak iç hatlarda Ankara Esenboğa havaalanını, dış hatlarda ise İstanbul'da hizmet veren uluslararası havaalanı İstanbul Havaalanını merkez havaalanı olarak kullanmaktadır. Bu sayede orta mesafede başarısı kesinlikle ispatlanmış olan Airbus 320 (ve türevi) ile Boeing 737-800 (ve türevi uçaklarla) bu kentleri son derece ekonomik olarak İstanbul'a bağlamaktadır. Uzun menzilli uçaklarla bu strateji desteklenerek İstanbul dünyanın en önemli aktarma merkezlerinden biri haline gelmiştir. Bu sistemin dünyada başarılı örnekleri arasında LondraFrankfurt New York, Singapur ve Dubai'yi sayabiliriz (Torum, 2010).

Ancak İstanbul'un Londra ve Frankfurt dışındaki bu havalimanlarına ve buralarda kurulu havayollarına karşı büyük bir avantajı vardır. Bu avantaj İstanbul merkezli bir operasyonda satın alma maliyetleri göreceli olarak oldukça düşük A320 ve B737'ler kullanmak mümkünken diğer şehirlerden aynı işi yapmak için çok daha pahalı uzun menzilli uçaklara gereksinim duyulmasıdır (Torum, 2010).

Türk Hava Yolları da 2008 yılından sonra bu oluşuma dahil olmayı tercih ederek önemli bir adım atmış oldu. Söz konusu adımın önemini basit bir örnekle açıklayabiliriz. Şöyle ki; Türk Hava Yolları üyelik öncesi tarifeli uçuş gerçekleştiremediği noktalara bilet satışı mümkün olmuyordu.

Bu üyelik ile birlikte güçlü bir ittifakın avantajlarından yararlanarak, yolcularına bağlantı sağlamaları için alternatifler sunmaya başlamıştır. Böylece, yolcuların Bağlantı Merkezleri ile uçak kaçırma stresi sona ermiştir.

Star Alliance üyesi firmalar, yolcuların bagaj bilgileri devamlı takip edilerek bagajların diğer bağlantılı uçuşlarına en kısa sürede ulaştırılması için gerekli özeni gösterdikleri gözlemlenmektedir. 
Bazı durumlarda da havayolu personeli, yolcuyu havalimanında karşılayarak transfer işleminin çok daha kolay bir şekilde yapılmasını olanaklı kılmaktadır. Star Alliance, bu hizmeti ile birlikte kalite standartlarını daha üst düzeye taşımayı hedeflemektedir.

Yukarıda da belirtildiği üzere, 2008 senesinde Star Alliance'a üye olması ile birlikte Türk Hava Yolları ittifakının avantajlarını önemli ölçüde değerlendirmiştir. Söz konusu üyelik nedeniyle yolcular bağlantılı uçuşlarla dünyanın herhangi bir noktasına sorunsuz olarak uçabilmektedir. Bunun yanı sıra, ittifaka üye havayolları arasında yapılan ortak uçuşlar nedeniyle de avantajlı bilet imkanlarından faydalanabilmektedirler. Ayrıca Star Alliance üyeliğinin oluşturduğu önemli bir bileşen olan hizmet kalitesinin en üst düzeye yükseltilmesi büyük önem arz etmektedir. $\mathrm{Bu}$ durum da yolcuların beklentilerini karşılamak bağlamında yaptıkları uçuşlara göre onlara daha fazla mil kazanma imkanı, üyeliğin seviyesine bağlı olarak dünyadaki özel yolcu salonlarını kullanma şansı gibi birçok avantajı da yolcuların hizmetine sunulmaktadır.

\section{2020 yılında Koronavirüs’ün Havayolu İşletmelerine Etkileri}

Küreselleşmenin etkisiyle Havacılık sektörünün hızlı bir gelişim gösterdiği dönemlerde sektörde sağlanan ivme ile birlikte, çeşitli faktörlerden kaynaklanan duraklama ve küçülme dönemleri olmuştur. Bunlara örnek olarak 1990-91 ve 2003 Körfez Savaşları, Eylül 2001 Terörist Saldırılarını, 2002 Sars virüsü krizi ve 2008 Küresel Ekonomik Krizi verebiliriz. Ancak COVID-19 gibi hava trafiğini felç olma noktasına getirecek kadar sektörü olumsuz şekilde etkileyen bu tür bir buhran yaşanmamıştır.

Bilindiği gibi, hava taşımacılığında iç ve dış hatlarda yolcular tarafından tercih edilmesinde özellikle güvenilirlik, güvenlik, hız ve zaman, konularında sahip olduğu avantajlar büyük önem arz etmektedir. $\mathrm{Bu}$ nedenle, söz konusu hassas dönemde özellikle Çin ile yolcu hareketliliğinin hava yolu ağları ile dünyadaki aktarma merkezlerine dağılımı, havalimanlarının yolcu yoğunluğunun artması ve solunum yolu ile bulaşıcı hastalıkların uçak içerisinde daha kolay yayılımı gibi faktörler salgının dünyada geniş bir alana yayılarak ortaya çıkmasını hızlandırmıştır (Akça, 2020:46).

Söz konusu dönemde bu durum Dünya Sağlık Örgütü (WHO) tarafından pandemi olarak kabul edilmiştir. Uluslararası kredi derecelendirme kuruluşu Moody's de Kovid-19'dan etkilenen havacılık sektörünün 2023'ten önce tamamen toparlanamayacağını ve sektörün çok önemli yapısal değişikliklerle karşı karşıya olduğunu açıklamıştır.

Hızla gelişmekte olan Türk havayolu taşımacılığının da söz konusu süreçte rakipleri gibi bazı mali kayıpları kaçınılmazdır. Ancak, ülkemizde bu konuda yapılan doğru yatırımları göz önüne aldığımızda bazı iş hacimlerinin ülkemize yönelerek değerlendirilmesi önem arz edebilir. Dolayısıyla yakın zamanda bu krizin bir firsata dönüşmesi büyük önem arz edecektir. Bu nedenle özellikle artan hacme karşı kriz yönetimini en iyi şekilde yürürlüğe sokarak ve tüm hazırlıkları buna göre yapıp çok kısa bir süre içinde talebi beklemek şu an için yeterli olacaktır (Düzgün, 2020).

Uluslararası Hava Taşımacılığı Birliği’ne göre, yolcu gelirlerinin 314 milyar dolar azalması bekleniyor. Salgının havayolu şirketlerine bu yılki maliyetinin de 113 milyar doları bulacağı öngörülüyor. IATA'ya göre, küresel ekonominin resesyona doğru gitmesinden ve seyahat kısıtlamalarından dolayı bu yıl yolcu talebinin geçen yıla göre \%48 azalabileceği raporunda vurgulamıştır. Havacılık sektöründe toparlanmanın uzun sürebileceğini ancak, havacılığın vazgeçilmezliğini sürdüreceği düşünülmekte, 2020'de \%40-60, 2021'de \%80 ve 2022'nin ilk 8 ayında \%100, müteakip y1llarda ise 2022'de elde edilen hacmin \%6-8 büyüyerek sürecin gelişeceği uzmanlar tarafından tahmin edilmektedir. 2028 yılına gelindiğinde ise 2019 yılının \%45'i oranında bir büyüme beklenmektedir (Düzgün, 2020).

IATA’ya göre Havacılık sektörünün geleceği 2050 yılında 16 milyara ulaşması beklenen yolcu sayısı ile umut vaat etmektedir. 2035 yılına kadar 33.070 adet yeni uçağın sektörün hizmetin girmesi tahmin edilmektedir. 33.070 adet yeni uçağın 32.430 adedi yolcu uçağı ve 650 adedi kargo uçağıdır.

Yeni yolcu uçağ talebinin \%40'1 yenileme ve \%60’1 büyüme amaçlı olup, yeni uçakların adet olarak \% 70 'i tek koridorlu uçakları temsil etmektedir. Parasal olarak ise yeni uçak siparişleri 5.2 Trilyon USD'lik bir miktara ulaşmaktadır (Kemer, 2020). 
Ülkemizin önde gelen havayolu taşımacılı̆̆ı şirketi THY'nin geleceğe dair talepleri küresel tahminler ile doğru yönde seyretmektedir. THY'nin Mart 2017 itibariyle 336 adet yolcu ve kargo uçağ1 bulunmakta olup, filonun 178 adetini tek koridorlu uçaklar oluşturmaktadır. Söz konusu tek koridorlu uçakların 110 adedi Boeing 737-800 ve 68 adedi de Airbus A 321-200’dür. THY'nin son yeni uçak alımı planına göre 2023 sonu itibariyle filo sayısının 421'e ulaşması öngörülmekte olup, bu sayının 342 adedini tek koridorlu uçaklar oluşturacaktır. THY 2017-2023 döneminde 169 adet yeni uçak teslim alacak ve ortalama filo yaşını da düşürecektir (Kemer, 2020).

\section{Sonuç}

Tüm dünyada büyük bir hızla etkisini göstermeye başlayan küreselleşme eğilimi, insanoğlunun yaşamının tüm noktalarına, sosyal olgularına, ekonomik durumuna, kültürlerine, yaşam tarzlarına, arzu ve isteklerine etki ederek bir değişim sürecini ortaya çıkarmaktadır. Bu değişim süreci ile yakından ilişkili olan işletmelerde kendilerini yepyeni bir sistemin içinde bulmuşlar, bu değişen ve gelişen sistemin bir parçası olma yolunda birtakım yenilikler yapmaya başlamışlardır.

Küreselleşme sürecinden en fazla etkilenen sektör ise havacilık sektörü olmuştur. Havayolu endüstrisinde artan turizm ve yükselen hizmet sektörleri sayesinde canlanma meydana gelmiştir. Havayolu işletmeleri artan rekabet koşulları ve pazara girişlerin kolaylaştırılması, yükselen talep ve artan kazanç durumları ile yeni bir takım yönetsel ve fonksiyonel değişimler yaşamışlardır. Havayolu işletmeleri değişen bu küresel koşullarda yeni yönetim teknikleri ile ilgili çalışmalar yaparak bu teknikleri bünyelerine uygulamaya başlamışlar ve küresel bir havayolu işletmesi özellikleri kazanmaları kaçınılmaz bir hale gelmiştir.

Küresel boyuttaki havayolu işletmeleri, maliyetlerini kontrol altında tutmak, etkinlik ve verimlilik sağlamak için dış kaynaklardan yararlanma, franchising, temel yeteneklerine yönelme, iş birlikleri, kalite yönetim sistemleri gibi teknikleri uygulamışlar ve daha iyi hizmet amacıyla işletme bütününe bu teknikleri yaymışlardır.

Küresel ve iç baskılar altında bulunan havayolu işletmeleri, küresel bir uçuş ağı oluşturarak pazardaki durumlarını muhafaza etmekte ve yeni pazarlara giriş için çalışmaktadırlar. Bu kapsamda havayolu işletmeleri, talep gören yeni pazarlardan pay alabilmek ve dünyanın her yanına kesintisiz uçabilmek için diğer havayolu grupları ile iş birliğine gitmiş, kendi iç bünyesinde ise, organizasyon değişikliklerine gitmişlerdir.

Üç büyük küresel havayolu ittifaklarından dünyada en büyük Pazar payına sahip Star Alliance seçili havalimanlarında, üyesi olan havayolu şirketlerinin check-in kontuarları ile ortak biletleme, bekleme salonlarını, bagaj tesislerini ve diğer servisleri paylaşmaktadır. Londra Heathrow Havaalanı Terminal 2'deki bina buna örnek olarak gösterilebilir. Burada Star Alliance üyesi havayolu şirketleri belirledikleri amaçlar doğrultusunda hedeflerini gerçekleştirebilmek için yeni binada faaliyetlerini yürütmeye devam etmektedirler.

Bilindiği gibi, havayolu uygulamalarında rötar yaptığında yolcular için en büyük korku kaynağı aktarmayı kaçırmalarıdır. Bu gibi durumlarda Star Alliance bağlantı merkezlerinde varılacak havaalanları için bagaj bilgisini izlenir, yolcunun ve bagajının aktarmaya yetişmesi için büyük bir çaba gösterilir. Uygulama sırasında gerektiğinde üye havayolu personeli sizi uçaktan karşılayarak transferinizi sorunsuz bir şekilde gerçekleştirmeye çalışır. Günümüzde söz konusu hizmet Star Alliance'ın dünya çapındaki başlıca "aktarma merkez" lerinde mevcuttur.

Küresel ittifaklar, merkez ve bağlı bileşen sistemlerini etkili bir şekilde kullanarak daha fazla küresel erişim ve kesintisiz bağlantılar sağlamıştır. Küresel Havayolu ittifakı olan Star Alliance 20. yılını 2017' de İstanbul'da kutlamış olup, Nisan 2008'de Star ittifakına 20. üye olarak Türk Hava Yolları da ittifaka katılımının 10. Yılını 2018'de kutlamıştır. 
$\mathrm{Bu}$ arada, yeni açılan İstanbul Havalimanı bünyesinde barındıracağı tesislerle hem hizmette hem de yolcuların ihtiyaçlarını en iyi şekilde karşılayacak iyi bir aktarma merkezi olacaktır.

Yukarıda açıklanan bilgiler ışığında, Küresel Havayolu İttifaklarının havacılık sektörüne olumlu katkılar sağladığg görülmüştür. 


\section{BEYANLAR}

Hakem Değerlendirmesi: Dış bağımsız

Çıkar Çatışması: Yazarlar arasında çıkar çatışması yoktur

Finansal Destek: Bu çalışma için finansal destek alınmamıştır

Katkı Payı Oranı: Her iki yazar eşit oranda katılım sağlamıştır. 


\section{KAYNAKÇA}

Akça, M. (2019). Avrasya Sosyal ve Ekonomi Araştırmaları Dergisi (ASEAD), s.46 https://www.researchgate.net/publication/341030884_COVID-19'un_Havacilik_Sektorune_Etkisi

Airline Alliances - Statistics \& Facts.(2019). Published by E. Mazareanu, https://www.statista.com/topics/4207/airline-alliances/ Erişim Tarihi: 16.11.2020

Berardino,F.; Cross, R. ve Arciuolo, F.(2000). Handbook of Airline Marketing,. McGraw-Hill company, s.459

Blacking D. (2009). Do The Global Alliances Provide Real Benefits fort he consumer? An Examination of Star Aliience, Oneworld and Skyteam, https://www.tcd.ie/Economics/assets/pdf/SER/2009/Deena_Blacking.pdf Erişim Tarihi: 20.11.2020

Button K. (2008). School of George Mason University, USAGlobal Forum on Transport and Environment in a Globalising World, Guadalajara, Mexico, The Impacts of Globalisation on International Air Transport https://www.researchgate.net/publication/341030884_COVID- 19'un_Havacilik_Sektorune_Etkisi Erişim Tarihi: 15.11.2020

Düzgün, M., Havacılık Sektörü 2028 de \%45 büyüyebilir, https://www.aa.com.tr/tr/sirkethaberleri/egitim/havacilik-sektoru-2028de-yuzde-45-buyuyebilir/657845 (Erişim Tarihi: 17.06.2020 )

Düzgün, M., Milyon dolarlar havada uçuyor: Kurtarma paketleriyle iflaslar önleniyor. https://www.yenisafak.com/ekonomi/milyar-dolarlar-havada-ucusuyor-kurtarma-paketleriyle-iflaslaronlenmeye-calisiliyor-3545249 (Erişim Tarihi: 17.06.2020)

García A.T. (2012). Analysis of Global Airline Alliances as a Strategy for International Network Development, Master of Science in Technology and Policy and Master of Science in Aeronautics and Astronautics , Mayıs 2012 , s..59 https://core.ac.uk/download/pdf/10127599.pdf Erişim Tarihi: 16.11.2020

Gerede E. (2017). Küreselleşmenin Farklılaşma Stratejisi İzleyen Havayolu İşletmelerine Etkisi ve Havayolu İşbirlikleri,s.141

https://www.researchgate.net/profile/Ender_Gerede/publication/322369364_Kuresellesmenin_Farklilas ma_Stratejisi_Izleyen_Havayolu_Isletmelerine_Etkisi_ve_Havayolu_Isbirlikleri/links/5a566cd6aca272 bb6963ecdd/Kueresellesmenin-Farklilasma-Stratejisi-Izleyen-Havayolu-Isletmelerine-Etkisi-veHavayolu-Isbirlikleri.pdf

Gerede, E. (2015). Havayolu Taşımacılığı ve Ekonomik Düzenlemeler Teori ve Türkiye Uygulaması,Sivil Havacılık Genel Müdürlüğü Yayınları, Ankara, s.105-106

Goetz A.R., Graham B. ve Geogr J Transp . (2004). 12(4): 265-276 Air transport globalization, liberalization and sustainability: post-2001 policy dynamics in the United States and Europe, https://www.ncbi.nlm.nih.gov/pmc/articles/PMC7125701/ Erişim Tarihi: 16.11.2020

Goldstein, J.; Pevehouse. (2015). Uluslararası İlişkiler, çev. Prof. Dr. Haluk Özdemir, BB101 Yayınları, 1. Bask1, s.79.,532,533

Harward Business Review,. (1989). Managing in a Borderless World by Kenichi Ohmae From the Magazine https://hbr.org/1989/05/managing-in-a-borderless-world, Erişim Tarihi: 19.11.2020

Heywood A. (2016). Küresel Siyaset, Çevirenler: Nasuh Uslu ve Haluk Özdemir, Adres Yayınları, 4.baskı, s.27

Ion D.C. (2011). Impact of globalization on airport industry,International conference of scientific paper Afases , 2011 Brasov-Romania, s.66-70, http://www.afahc.ro/ro/afases/2011/manag/Ion.pdf Erişim Tarihi: 15.11.2020 
Kardaş, Ş. ve Balcı, A. (2017). Uluslararası İlişkilere Giriş, Küreselleşme, E. Fuat Keyman, Küre Yayınları, 6.Basım, s.510.

Kaya M. ve Aydemir C. (2011). Küreselleşmenin Tarihsel Gelişimi, Dicle Üniversitesi İ̈BF Dergisi, Cilt:1, Sayı:1, s.15, https://dergipark.org.tr/tr/download/article-file/370656 Erişim Tarihi: 20.11.2020

Kemer, N.K., Küresel Sivil Havacılık Sektörü, https://www.airturkhaber.com/yazarlar/namik-kemal-kemer/kuresel-sivil-havacilik-sektoru/ (Erişim Tarihi: 26.05.2020)

Keyman, F.ve Sarıbay, A.Y. (1998). Küreselleşme, Siyaset ve Toplumsal Yaşam, Küreselleşme, Sivil Toplum ve İslam, Vadi Yayınları, Konya, s.26.

Keyman E.F., Lorasdağı, B. ve Vardar, D. (2015) T.C. Anadolu Üniversitesi Yayını No:3003 Uluslararası İlişkilere Giriş, Ağustos, s.26

Kıvılcım, F. (2013). Küreselleşme kavramı ve Küreselleşme Sürecinin Gelişmekte olan ülke Türkiye açısından Değerlendirilmesi, Sosyal ve Beşeri Bilimler Dergisi, Cilt:5,No 1, s.221 https://dergipark.org.tr/tr/download/article-file/117355 Erişim Tarihi: 15.11.2020

Konukcu, Y. (2018). Devletlerin Küresel ve Bölgesel Güç Olma Stratejileri, Uluslararası Ekonomi Siyaset İnsan ve Toplum Bilimleri Dergisi, Cilt.1, Say1 3, s.207 https://dergipark.org.tr/tr/download/article-file/554527 Erişim Tarihi: 02.12 .2020

Kürkçü D.D. (2013). Küreselleşme Kavramı ve Küreselleşmeye yönelik Davranışlar, İKÜ Dergiler, Cilt:3, Sayı:2, s.4-5, https://dergipark.org.tr/en/download/article-file/138361 Erişim Tarihi: 19.11.2020

Mbembe, A. (2018). The idea of a borderless World, Politics, https://africasacountry.com/2018/11/the-idea-of-a-borderless-world. 20.11.2020

Military Globalization, https://en.wikipedia.org/wiki/Military_globalization Erişim Tarihi: 22.11.2020

Önen, V. (2018). Sivil Hava Yolu Taşımacılığında Pazar Payının Arttırılmasına Yönelik Rekabetçi Stratejilerin Geliştirilmesi Kriter Yayınevi, Birinci Baskı, s.103

https://www.researchgate.net/profile/Vahap_Onen/publication/341358337_Sivil_Hava_Yolu_Tasimacil iginda_Pazar_Payini_Artirmaya_Yonelik_Rekabetci_Stratejilerin_Gelistirilmesi/links/5ebc4157458515 626ca7e05a/Sivil-Hava-Yolu-Tasimaciliginda-Pazar-Payini-Artirmaya-Yoenelik-RekabetciStratejilerin-Gelistirilmesi.pdf, 05.12.2020

Ohmae., K., (2007). The Next Global Stage, , Pearson Education LTD.USA, P.20-24

http://ptgmedia.pearsoncmg.com/images/9780131479449/samplepages/013147944X.pdf Erişim Tarihi: 02.12 .2020

Öymen, O. (2000). Geleceği Yakalamak, Remzi Kitapevi, İstanbul, s.26

Özalp,E.; Kırel, Ç. (2001). Örgütsel Davranış, Eskişehir Anadolu Üniversitesi Yayınları, No.149, s.18.

Özerkmen N., "Uluslararası Eşitsizliği Derinleştiren Bir Süreç Olarak Ekonomik Küreselleşme”, Ankara Üniversitesi Dil ve Tarih Coğrafya Fakültesi Dergisi, 2004, s.135.

http://dergiler.ankara.edu.tr/dergiler/26/1008/12229.pdf Erişim Tarihi: 20.11.2020

Torum, O. (2010). Airport Haber, https://www.airporthaber.com/kose-yazilari/konugumla-thy8217na-elestirilerve-oneriler-654y.html Erişim Tarihi: 26.02.2021

Ülgen, H.,ve Mirze, K., İşletmelerde Stratejik Yönetim, 7.Baskı, Beta Yayınları, Mart 2014, s.309.

Viotti P.; Kauppi, M., Uluslararası İlişkiler ve Dünya Siyaseti, çev.Ayşe Özbay Erozan, Nobel Akademik Yayıncılık, 5.Basımdan çeviri, Ekim 2014, s.150-152 
Zhı H.Wang ve Evans Michael, Strategic Classification and Examination of the Development of current Airline Activities, Journal of Air Transportation, vol:7,no:2,2002, s.73.

WTO, dönemin genel müdürü olan Pascal Lamy tarafından "Humanising Globalization” konulu konuşma, Şili: 30 Ocak 2006 https://www.wto.org/english/news_e/sppl_e/sppl16_e.htm Erişim Tarihi: 20.11.2020 